\title{
Hedgehog pathway inhibitors - current status and future prospects
}

\author{
Asfandyar Sheikh", Arsalan Ahmad Alvi, Hafiz Muhammad Aslam and Abdul Haseeb
}

\begin{abstract}
The Hedgehog $(\mathrm{Hh})$ proteins comprise a group of secreted proteins that regulate cell growth, differentiation and survival. Inappropriate activation of the Hh signaling pathway has been implicated in the development of a variety of cancers. Hedgehog pathway inhibitors are a relatively new class of therapeutic agents that act by targeting the proteins involved in the regulation of Hh pathway (PTCH, SMO and Gli). Together, they serve as exciting new prospects, with a bright future, both alone or as an adjuvant to the more traditional anti-cancer drugs.
\end{abstract}

\section{Letter}

The Hedgehog (Hh) proteins comprise a group of secreted proteins that regulate cell growth, differentiation and survival [1]. They are involved in organogenesis, and have been shown to promote adult stem cell proliferation [2,3]. Inappropriate activation of the $\mathrm{Hh}$ signaling pathway has been implicated in the development of several types of cancers including prostate, lung, pancreas, breast, brain and skin [4-9].

Sonic Hedgehog (Shh) is the best studied ligand of $\mathrm{Hh}$ pathway in vertebrates. In the absence of the ligand, the Patched (PTCH) receptor inhibits Smoothened (SMO), a downstream protein in the pathway. Binding of Shh to PTCH alleviates this inhibition, thus regulating the expression of Gli transcription factors [10]. Loss-offunction mutations of $\mathrm{PTCH}$, gain-of-function mutations of SMO and misexpression of the Gli2 and Gli3 have been associated with tumor formation and maintenance in animal models of medulloblastoma and basal cell carcinoma of the skin [11-14]. Other studies have pointed towards Hedgehog signaling having an important role in angiogenesis (by increasing angiopoietin-1 and angiopoietin-2), metastasis (by increasing Snail expression) and suppression of apoptosis (by increasing Cyclins and anti-apoptotic factors and decreasing pro-apoptotic genes such as Fas) [15-18].

Hedgehog pathway inhibitors are a relatively new class of therapeutic agents that act by targeting the proteins

\footnotetext{
* Correspondence: asfandyarsheikh@gmail.com

Dow Medical College, Dow University of Health Sciences, Baba-e-Urdu Road, Karachi 74200, Pakistan
}

involved in the regulation of $\mathrm{Hh}$ pathway. Cyclopamine is the prototype inhibitor of the Shh pathway that inactivates SMO by binding to its hepta-helical bundle [19]. It is currently undergoing preclinical and clinical studies as an anticancer agent in basal cell carcinoma, medulloblastoma and rhabdomyosarcoma [20,21]. Saridegib (IPI926), a synthetic analog of cyclopamine, has shown positive results in Phase I clinical trial of advanced solid tumors [22]. Similarly, itraconazole, an antifungal drug, has also been shown to suppress growth of medulloblastoma in mice allograft models [23]. This compound acts as an SMO antagonist, in a manner distinct from its anti-lanosterol activity in fungi (other azole drugs have not been found to have this effect). Other candidates for future trials include Novartis' LDE-225, Millennium Pharmaceuticals' TAK-441, Exelixis/ Bristol-Myers Squibb's BMS-833923 (XL139) and Pfizer's PF-04449913 [24,25].

Vismodegib (IPI-926; Erivedge: Genentech, South St Francisco, CA, USA) has been recently approved by the FDA for treatment of advanced basal cell carcinoma [26]. However, like other drugs in the category, it also has an adverse effect profile. Due to its mechanism of action, it is contraindicated during pregnancy, as it is teratogenic, embryotoxic and fetotoxic [27]. Other adverse reactions include alopecia, muscle spasms, weight loss, fatigue, GIT disturbances and arthralgias [27].

The approval of Vismodegib by the FDA can prove to be the beginning of a new era in anti-cancer therapeutics. Other drugs targeting the Hh pathway are likely to follow. Together, they serve as exciting new prospects, 
with a bright future, both alone or as an adjuvant to the more traditional anti-cancer drugs.

\section{Competing interests}

The authors declare that they have no conflict of interests.

\section{Authors' contributions}

AS was involved in choosing the topic and drafting the initial manuscript. $\mathrm{HMA}, \mathrm{AAA}$ and $\mathrm{AH}$ were involved in critically revising the manuscript, listed in decreasing order of their contributions. The authors have read and approved the manuscript. The authors did not receive any financial support/ grant.

Received: 2 September 2012 Accepted: 31 October 2012

Published: 1 November 2012

\section{References}

1. Varjosalo M, Taipale J: Hedgehog: functions and mechanisms. Genes Dev 2008, 22(18):2454-2472.

2. Ingham PW, McMahon AP: Hedgehog signaling in animal development: paradigms and principles. Genes Dev 2001, 15(23):3059.

3. Bhardwaj G, Murdoch B, Wu D, Baker D, Williams K, Chadwick K, Ling L, Karanu F, Bhatia M: Sonic hedgehog induces the proliferation of primitive human hematopoietic cells via BMP regulation. Nat Immuno/ 2001, 2(2):172-180.

4. Sheng T, Li C, Zhang X, Chi S, He N, Chen K, McCormick F, Gatalica Z, Xie J: Activation of the hedgehog pathway in advanced prostate cancer. $\mathrm{Mol}$ Cancer 2004, 3(1):29.

5. Watkins DN, Berman DM, Burkholder SG, Wang B, Beachy PA, Baylin SB: Hedgehog signalling within airway epithelial progenitors and in smallcell lung cancer. Nature 2003, 422(6929):313-317.

6. Thayer SP, Di Magliano MP, Heiser PW, Nielsen CM, Roberts DJ, Lauwers GY, Qi YP, Gysin S, Fernández-del Castillo C, Yajnik V: Hedgehog is an early and late mediator of pancreatic cancer tumorigenesis. Nature 2003, 425(6960):851-856.

7. Liu S, Dontu G, Mantle ID, Patel S, Ahn N, Jackson KW, Suri P, Wicha MS: Hedgehog signaling and Bmi-1 regulate self-renewal of normal and malignant human mammary stem cells. Cancer Res 2006, 66(12):6063.

8. Dellovade T, Romer JT, Curran T, Rubin LL: The hedgehog pathway and neurological disorders. Annu Rev Neurosci 2006, 29:539-563.

9. Bale $A E, Y u K$ : The hedgehog pathway and basal cell carcinomas. Hum Mol Genet 2001, 10(7):757-762.

10. Michaud EJ, Yoder BK: The primary cilium in cell signaling and cancer. Cancer Res 2006, 66(13):6463.

11. Oro AE, Higgins KM, Hu Z, Bonifas JM, Epstein EH Jr, Scott MP: Basal cell carcinomas in mice overexpressing sonic hedgehog. Science 1997, 276(5313):817-821

12. Xie J, Murone M, Luoh S-M, Ryan A, Gu Q, Zhang C, Bonifas JM, Lam C-W, Hynes M, Goddard A, et al: Activating Smoothened mutations in sporadic basal-cell carcinoma. Nature 1998, 391(6662):90-92.

13. Nilsson M, Undèn AB, Krause D, Malmqwist U, Raza K, Zaphiropoulos PG, Toftgård R: Induction of basal cell carcinomas and trichoepitheliomas in mice overexpressing GLI-1. Proc Natl Acad Sci 2000, 97(7):3438-3443.

14. Grachtchouk M, Mo R, Yu S, Zhang X, Sasaki H, Hui C, Dlugosz AA: Basal cell carcinomas in mice overexpressing Gli2 in skin. Nat Genet 2000, 24(3):216-217

15. Lee SW, Moskowitz MA, Sims JR: Sonic hedgehog inversely regulates the expression of angiopoietin-1 and angiopoietin-2 in fibroblasts. Int J Mol Med 2007, 19(3):445.

16. Li X, Deng W, Nail CD, Bailey SK, Kraus MH, Ruppert JM, Lobo-Ruppert SM: Snail induction is an early response to Gli1 that determines the efficiency of epithelial transformation. Oncogene 2005, 25(4):609-621.

17. Adolphe C, Hetherington R, Ellis T, Wainwright B: Patched 1 functions as a gatekeeper by promoting cell cycle progression. Cancer Res 2006 66(4):2081-2088

18. Athar M, Li C, Tang X, Chi S, Zhang X, Kim AL, Tyring SK, Kopelovich L, Hebert J, Epstein EH, et al: Inhibition of smoothened signaling prevents ultraviolet B-induced basal cell carcinomas through regulation of fas expression and apoptosis. Cancer Res 2004, 64(20):7545-7552.
19. Chen JK, Taipale J, Cooper MK, Beachy PA: Inhibition of hedgehog signaling by direct binding of cyclopamine to Smoothened. Genes Dev 2002, 16(21):2743-2748.

20. Kolterud $\AA$, Toftgård R: Strategies for Hedgehog inhibition and its potential role in cancer treatment. Drug Discovery Today: Therapeutic Strategies 2007, 4(4):229-235.

21. Taipale J, Chen JK, Cooper MK, Wang B, Mann RK, Milenkovic L, Scott MP, Beachy PA: Effects of oncogenic mutations in smoothened and patched can be reversed by cyclopamine. Nature 2000, 406(6799):1005-1009.

22. Rudin C, Jimeno A, Miller W Jr, Eigl B, Gettinger S, Chang A, Faia K, Sweeney J, Loewen G, Ross R: A phase 1 study of IPI-926, a novel hedgehog pathway inhibitor, in patients with advanced or metastatic solid tumors. Surgery 2011, 32:94.

23. Kim J, Tang JY, Gong R, Kim J, Lee JJ, Clemons KV, Chong CR, Chang KS, Fereshteh M, Gardner D, et al: Itraconazole, a commonly used antifungal that inhibits hedgehog pathway activity and cancer growth. Cancer Cell 2010, 17(4):388-399.

24. Tremblay MR, McGovern K, Read MA, Castro AC: New developments in the discovery of small molecule Hedgehog pathway antagonists. Curr Opin Chem Biol 2010, 14(3):428-435.

25. McMillan R, Matsui W: Molecular Pathways: The Hedgehog Signaling Pathway in Cancer. Clinical Cancer Research 2012, 18(18):4883-4888.

26. Dlugosz A, Agrawal S, Kirkpatrick P: Vismodegib. Nat Rev Drug Discov 2012 11(6):437-438

27. Genentech: Erivedge [vismodegib; prescribing information]. South San Francisco, CA: Genentech, Inc; 2012

doi:10.1186/1750-9378-7-29

Cite this article as: Sheikh et al: Hedgehog pathway inhibitors - current status and future prospects. Infectious Agents and Cancer 2012 7:29.

\section{Submit your next manuscript to BioMed Central and take full advantage of:}

- Convenient online submission

- Thorough peer review

- No space constraints or color figure charges

- Immediate publication on acceptance

- Inclusion in PubMed, CAS, Scopus and Google Scholar

- Research which is freely available for redistribution 